\title{
Coexistence of GABA Receptors and GABA-Modulin in Primary Cultures of Rat Cerebellar Granule Cells
}

\author{
F. M. Vaccarino, H. Alho, M. R. Santi, and A. Guidotti \\ Fidia-Georgetown Institute for the Neurosciences, Washington, D.C. 20007
}

GABA-modulin (GM), a basic polypeptide purified from rat brain synaptosomes, which is an allosteric inhibitor of GABA recognition sites, has been detected in primary cultures of cerebellar interneurons enriched in granule cells by immunohistochemistry, using a specific antibody raised in rabbit injected with GM purified from rat brain synaptosomes. In these cultures, GM is expressed by the granule cells, which are postsynaptic to GABAergic interneurons, but not by glial cells. In rat cerebellar sections anti-GM antiserum intensely stains the granular cell layer and Purkinje cell dendrites and cell bodies. GM has been purified from the cerebellar granule cell cultures and appears to be identical under biochemical, immunological, and functional criteria to authentic GM purified from rat brain synaptosomes. Granule cell cultures devoid of GABAergic neurons contain the $\mathrm{GABA} / \mathrm{BZ} / \mathrm{Cl}^{-}$receptor complex; in fact, intact cell monolayers, incubated in physiological buffer at $25^{\circ} \mathrm{C}$, express ${ }^{3} \mathrm{H}$-muscimol and ${ }^{3} \mathrm{H}$ flunitrazepam binding sites, which are comparable to the sites detected in cell membrane preparations and which modulate each other reciprocally. It is concluded that GM might participate in the supramolecular organization of the GABA receptor complex, perhaps functioning as a modulator of this receptor protein.

Transmitter receptor function can be modulated by regulatory influences either at the ligand-binding domain or at the signaltransduction domain; thus, receptors can become "decisionmaking devices" adjusting their signal-transduction efficiency continuously. In this capacity resides the receptor's ability to optimize the interneuronal exchange of information in the face of changes in the synaptic microenvironment. Specific membrane-associated proteins participate in this modulation; for example, guanine nucleotide binding proteins, which are highly concentrated in neuronal membranes (Sternweis and Robishaw, 1984), not only are involved in the regulation of receptor-mediated activation of adenylate cyclase and polyphosphoinositide phosphodiesterase (Lefkowitz et al., 1982; Cockroft and Gomperts, 1985), but also regulate the affinity of several recognition

\footnotetext{
Received Jan. 7, 1986; revised June 30, 1986; accepted July 7, 1986.

The antiserum to GAD was provided through the Laboratory of Clinical Science, NIMH, where it was developed under the supervision of Dr. Irwin J. Kopin with Drs. Wolfgang Oertel, Donald E. Schmechel, and Marcel Tappaz. Effective use in immunocytochemistry was greatly aided through the laboratory of Enrico Mugnaini (University of Connecticut, Storrs). Helpful suggestions were given by Dr. G. Hashim, St. Luke's Hospital, New York, for the development of the anti-GM antiserum.

Correspondence should be addressed to Alessandro Guidotti, Fidia-Georgetown Institute for the Neurosciences, Georgetown University, 3900 Reservoir Road, N.W., Washington, D.C. 20007
}

Copyright (C) 1987 Society for Neuroscience $0270-6474 / 87 / 010065-12 \$ 02.00 / 0$ sites, including that of beta-adrenergic receptors (Rodbell, 1980). Regulation by membrane-bound proteins is not unique to receptors coupled to enzymes: In the case of the chloride channelcoupled GABA recognition sites, a polypeptide has been isolated from synaptosomal membrane preparations, termed GABAmodulin (GM) (Guidotti et al., 1982; Vaccarino et al., 1985), which modifies the number of high-affinity GABA-recognition sites.

Structurally, GM is a basic polypeptide, which has been purified and characterized and appears to be located selectively in the synaptosomal fraction of rat brain (Vaccarino et al., 1985). It shares a number of characteristics with a well-known class of basic proteins that were isolated from myelin and, in particular, with the small myelin basic protein (SMBP) (Dunkley and Carnegie, 1974; Vaccarino et al., 1985). However, GM can be differentiated from SMBP because of its molecular weight, amino acid composition, tryptic peptide map, and lack of absolute homology in amino acid sequence (Vaccarino et al., 1985). It is conceivable that GM represents a new class of basic proteins contained in the synaptic environment that may modulate neurotransmitter recognition site characteristics. To test whether GM could be colocalized with the GABA/benzodiazepine (BZ)/ $\mathrm{Cl}^{-}$receptor complex, we used primary cultures from neonatal rat cerebellum as a neuronal model (Balazs et al., 1982; Gallo et al., 1982, 1985). These cultures, which have been shown to differentiate in vitro both morphologically and functionally (Gallo et al., 1982; Levi et al., 1984), contain a predominance of granule cells (morc than $90 \%$ of the total cells) that receive GABAergic innervation by a less abundant population of GABAergic interneurons (see Results).

The results presented here indicate that granule cells physiologically contain a high amount of GM and express GABA and $B Z$ recognition sites in their membrane, in agreement with the idea that GM may be functionally associated with postsynaptic GABA receptors.

\section{Materials and Methods \\ Granule cell culture}

Primary cultures of cerebellar interneurons enriched in granule cells were obtained from 8-d-old rat cerebellum (Wilkin et al., 1976; Levi et al., 1984; Gallo et al., 1985). Cells were plated $\left(2.5 \times 10^{6}\right.$ cells/dish $)$ onto $36 \mathrm{~mm}$ Falcon dishes coated with $5 \mu \mathrm{g} / \mathrm{ml}$ poly(L-lysine) $(\mathrm{MW}=$ $\left.70-150 \times 10^{3}\right)$ and were cultured in the following medium: Basal Eagle's medium (Flow Laboratories), 10\% fetal calf serum (GIBCO, Chagrin Falls, Ohio), $25 \mathrm{~mm} \mathrm{KCl}, 2 \mathrm{~mm}$ glutamine, and $100 \mu \mathrm{g} / \mathrm{ml}$ gentamycin (GIBCO). Cytosine arabinofuranoside (Ara-C; $10 \mu \mathrm{M}$ ) (Sigma Chemical Company, St. Louis) was added after $16 \mathrm{hr}$ in vitro to inhibit the replication of non-neuronal cells. Both for histochemical and binding studies, 8-d in vitro cultures were used; however, for binding experiments, the incubation medium was removed and substituted with fresh medium after $7 \mathrm{~d}$ in culture. Using this procedure, GABAergic interneurons 
Figure 1. Saturation isotherms and Scatchard plots of ${ }^{3} \mathrm{H}$-muscimol $(A)$ and ${ }^{3} \mathrm{H}$-flunitrazepam $(B)$ binding to intact granule cell monolayers. Assays were performed in the presence of 2-160 nM ligand concentration range for ${ }^{3} \mathrm{H}$-muscimol and 2.5-50 nM for ${ }^{3} \mathrm{H}$-flunitrazepam. In both $A$ and $B$, the points show the data of 1 representative experiment, which was repeated 3 times using different preparations of granule cell cultures. Bound $={ }^{3} \mathrm{H}$-muscimol or ${ }^{3} \mathrm{H}$ flunitrazepam specifically bound, calculated by subtracting the radioligand bound in the presence of $10^{-3} \mathrm{M} \mathrm{GABA}$ or $10^{-6} \mathrm{M}$ clonazepam, respectively, from the total binding.

disappear from the culture, whereas granule cells remain intact (Aloisi et al., 1985).

\section{$G A B A$ determination}

Granule cell cultures were incubated at $25^{\circ} \mathrm{C}$ in $0.9 \mathrm{ml}$ of Locke's solution $\left(154 \mathrm{~mm} \mathrm{NaCl}, 5.6 \mathrm{~mm} \mathrm{KCl}, 3.6 \mathrm{~mm} \mathrm{NaHCO}, 2.3 \mathrm{~mm} \mathrm{CaCl}_{2}, 1 \mathrm{~mm}\right.$ $\mathrm{MgCl}_{2}, 5.6 \mathrm{~mm}$ glucose, $5 \mathrm{~mm}$ HEPES, $\mathrm{pH}$ 7.4). The cell monolayer and an aliquot of the incubation medium were extracted with $0.4 \mathrm{~N} \mathrm{HClO}_{4}$ containing $5 \mathrm{nmol} / \mathrm{ml}$ citrulline as standard. After centrifugation, the $33,000 \times g$ supernatant was injected into a high-pressure liquid chromatography (HPLC) system equipped with a $3.1 \mathrm{~mm} \times 25 \mathrm{~cm}$ Bio-Rad Aminex A9 cation-exchange resin column maintained at $55^{\circ} \mathrm{C}$. Amino acids were eluted from the column by $0.25 \mathrm{~m}$ sodium acetate buffer $(\mathrm{pH}$ 4.7) and quantified fluorimentrically as described by Schmid (1980).

\section{${ }^{3} \mathrm{H}$-muscimol and ${ }^{3} \mathrm{H}$-flunitrazepam binding studies}

Intact cells. The binding of various ligands was studied at equilibrium as described by Gallo et al. (1985). Briefly, granule cell monolayers were washed once with Locke's solution and then incubated at $25^{\circ} \mathrm{C}$ with 1 $\mathrm{ml}$ of Locke's solution containing ${ }^{3} \mathrm{H}$-muscimol or ${ }^{3} \mathrm{H}$-flunitrazepam (both from New England Nuclear, Boston) plus drugs to be studied. Since for ${ }^{3} \mathrm{H}$-muscimol binding equilibrium is reached in $10 \mathrm{~min}$, this ligand was incubated for $15 \mathrm{~min}$. ${ }^{3} \mathrm{H}$-flunitrazepam was incubated for $30 \mathrm{~min}$. To stop the incubation, the monolayer was rapidly washed with
A.
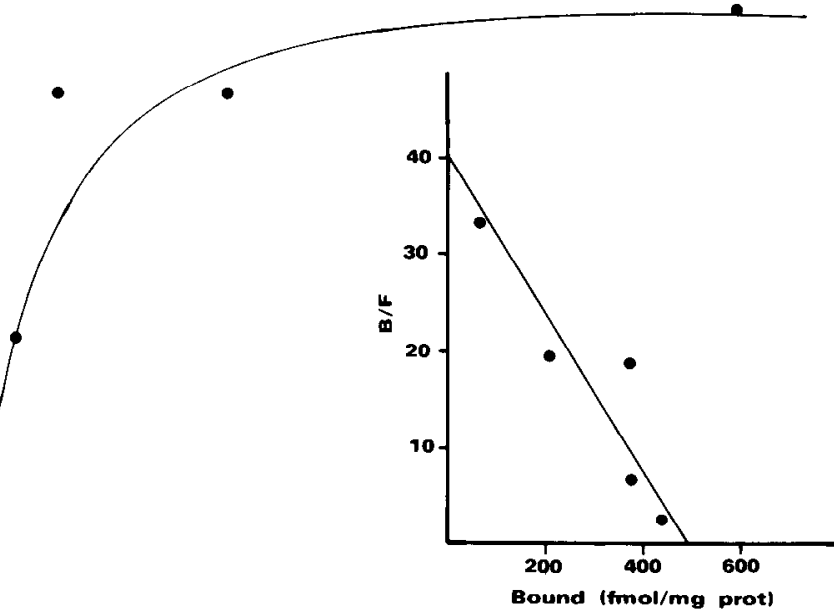

20

40

60

3.

3H Muscimol, nM

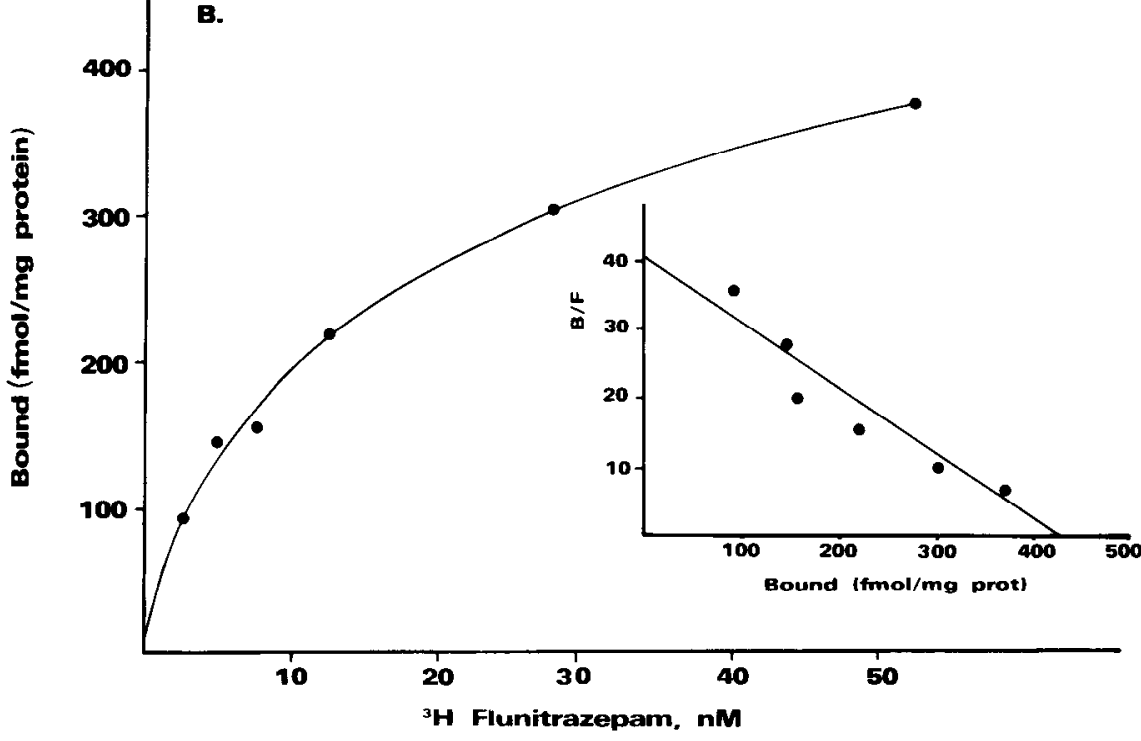

Locke's solution, the cells were resuspended in $1 \mathrm{ml}$ of $0.1 \mathrm{~N} \mathrm{NaOH}$, and the $\mathrm{NaOH}$ suspension was used for counting the radioactivity and for protein determination (Lowry et al., 1951). The specific binding was calculated by subtracting the nonspecific binding (radiolabel bound in the presence of $10^{-3} \mathrm{M}$ nonradioactive GABA or $10^{-6} \mathrm{M}$ nonradioactive clonazepam, respectively) from the total ${ }^{3} \mathrm{H}$-muscimol or ${ }^{3} \mathrm{H}$-flunitrazepam binding. The radiolabel bound to the plastic dishes was subtracted from the value of all samples. Using concentrations lower than $50 \mathrm{~nm}$ for ${ }^{3} \mathrm{H}$-muscimol or $30 \mathrm{~nm}$ for ${ }^{3} \mathrm{H}$-flunitrazepam, $70 \%$ of the total binding was specific.

Crude membranes. Crude rat brain synaptic membranes, prepared according to Enna and Snyder (1977), were frozen-thawed and treated with $0.05 \%$ Triton-X 100 just before ${ }^{3} \mathrm{H}$-muscimol binding (Guidotti et al., 1982). Membranes from granule cells were prepared by harvesting the cultures in ice-cold $\mathrm{H}_{2} \mathrm{O}$ followed by homogenization with Polytron and freezing. The day of the experiment, the membranes were washed once with $50 \mathrm{~mm}$ 'Tris- $\mathrm{HCl}, \mathrm{pH} 7.4$, resuspended in Locke's solution and incubated $\left(100 \mu \mathrm{g}\right.$ /protein tube) at $25^{\circ} \mathrm{C}$ with ${ }^{3} \mathrm{H}$-muscimol or ${ }^{3} \mathrm{H}$-flunitrazepam for 10 or $30 \mathrm{~min}$, respectively. ${ }^{3} \mathrm{H}$-flunitrazepam assay was terminated by filtration through Whatman GF/C filters, while ${ }^{3} \mathrm{H}$ muscimol assay was terminated by centrifugation (Massotti et al., 1981).

\section{Preparation of the anti-GM antiserum}

Purified GM, $500 \mu \mathrm{g}$ (Vaccarino et al., 1985), emulsified in Freund's complete adjuvant enriched with $4.5 \mathrm{mg} / \mathrm{ml}$ Mycobacterium butyricum 
Table 1. Inhibitory potency of benzodiazepines and $\beta$-carboline derivatives on ${ }^{3} \mathrm{H}$-flunitrazepam binding to granule cell monolayers and granule cell membranes

\begin{tabular}{lll} 
& \multicolumn{1}{l}{$K_{i}(\mathrm{nM})$} & \\
\cline { 2 - 3 } Ligand & Cell monolayers & Cell membranes \\
\hline Flunitrazepam & $6.5 \pm 0.31$ & $4.4 \pm 0.23$ \\
Clonazepam & $6.5 \pm 0.21$ & \\
Diazepam & $23 \pm 1.9$ & $18 \pm 0.91$ \\
R015-1788 & $3.9 \pm 0.3$ & \\
DMCM & $3.0 \pm 0.52$ & $3.3 \pm 0.13$ \\
$\beta$-CCM & $7.7 \pm 0.55$ & \\
$\beta$-CCE & $3.9 \pm 0.41$ & \\
\hline
\end{tabular}

${ }^{3} \mathrm{H}$-flunitrazepam binding to granule cell monolayers and granule cell membranes was performed as described in Materials and Methods. The mean inhibitory concentration $\left(\mathrm{IC}_{50}\right)$ was obtained from a semilogarithmic plot of the dose-response curve derived from the ligand inhibition of ${ }^{3} \mathrm{H}$-flunitrazepam binding. The inhibition constant $\left(K_{)}\right)$was calculated with the equation: $K_{i}=\mathrm{IC}_{50} / 1+[\mathrm{L}] / K_{d}$ where $[\mathrm{L}]$ is the radioligand concentration $(3.0 \mathrm{nM}$ for cell monolayers and $1 \mathrm{nM}$ for cell membranes) and $K_{d}$ is the dissociation constant of the ligand. The $K_{d}$ values were obtained from the Scatchard plots (Fig. $1 B$ and Results). The values represent the means \pm SEM of 3 separate experiments. Abbreviations: R015-1788, ethyl-8fluoro-5,6-dihydro-5-methyl-6-oxo-4-H-imidazo $[1-5 \mathrm{a}]-[1,4]$ benzodiazepine3-carboxylate; DMCM, methyl-6,7-dimethoxy-4-ethyl- $\beta$-carboline-3-carboxylate; $\beta$-CCM, methyl- $\beta$-carboline-3-carboxylate; $\beta$-CCE, ethyl- $\beta$-carboline-3-carboxylate.

powder (Difco) was injected subcutaneously into a rabbit. The animal was boosted 4 weeks later with GM $(250 \mu \mathrm{g})$ emulsified in incomplete Freund's adjuvant (Sigma) and after another week the rabbit was bled. The anti-GM antiserum showed a weak cross-reaction with myelin basic proteins (MBPs). To eliminate this cross-reactivity, the antiserum was routinely preabsorbed with MBPs using the method of Calabrese (1984). Briefly, an excess of SMBP and large myelin basic protein (LMBP) was absorbed in the wells of a 96 well microtitration plate (Flow Laboratories, McLean, VA). After blocking the unspecific sites with $10 \%$ fetal calf serum in PBS containing $0.5 \%$ BSA (PBS/FCS), the wells were filled with $200 \mu \mathrm{l}$ of anti-GM antiserum diluted 1:100 in PBS/FCS. After 1 hr reaction at $25^{\circ} \mathrm{C}$, the antiserum solution was transferred to other wells (coated with MBPs and treated with PBS/FCS as above) and incubated for an additional hour. This operation was repeated once more for a total of $3 \mathrm{hr}$ incubation.

\section{Radioimmunoassay}

Radioimmunoassay (RIA) was performed as follows. Samples to be tested were diluted in PBS plus 5\% BSA (PA buffer) containing $2 \mathrm{mg} /$ $\mathrm{ml}$ histone type II A (Sigma; PAH buffer) and assayed in the following system: $50 \mu \mathrm{l}$ of diluted sample, $100 \mu \mathrm{l}$ of MBPs-preabsorbed anti-GM antiserum diluted 1:1000 in PA buffer, $50 \mu \mathrm{l}$ of ${ }^{125} \mathrm{I}-\mathrm{GM}$ diluted in PAH buffer to have approximately $20,000 \mathrm{cpm} / 0.5 \mathrm{ng} /$ assay. After incubating the samples overnight at $4^{\circ} \mathrm{C}$, bound and free antigen were separated by adding $300 \mu \mathrm{l}$ of a suspension of protein A (Sigma; $0.25 \%$ in PBS) and incubating for $1 \mathrm{hr}$ at $4^{\circ} \mathrm{C}$. After centrifugation $(20 \mathrm{~min}$ at $3000 \times$ $g$ ), the supernatants were aspirated, the pellets washed once with PBS, and then counted for ${ }^{125} I$ in an automatic gamma counter.

\section{Preparation of iodinated basic proteins}

GM or SMBP (10 $\mu \mathrm{g}$, diluted in $100 \mu \mathrm{lPBS}$ ) was treated with approximately $2 \mathrm{mCi}$ of ${ }^{125}$-iodine and 3 iodo-beads (Pierce Chemical Company, Rockford, IL) for $15 \mathrm{~min}$ at $25^{\circ} \mathrm{C}$. The reaction was stopped by adding $700 \mu \mathrm{l}$ of $0.1 \mathrm{M}$ acetic acid, and the sample was desalted with a Bio-Gel P-2 column eluted with $0.1 \mathrm{M}$ acetic acid containing 1\% BSA. The purity of the iodinated material was tested by reverse-phase HPLC (see below).

\section{Purification of antibodies}

IgG immunoglobulins were purified by chromatography on protein ASepharose (Pharmacia) (Lindmark et al., 1983). Briefly, the antiserum was diluted $1: 5$ with $0.1 \mathrm{M}$ citrate buffer $(\mathrm{pH} 6.2)$ and applied to a $7 \mathrm{ml}$ column of protein A-Sepharose previously equilibrated with the same
Table 2. Inhibitory potency of GABA receptor ligands ${ }^{3} \mathrm{H}-\mathrm{muscimol}$ binding to intact granule cell monolayers

\begin{tabular}{lc} 
Ligand & \multicolumn{1}{c}{$K_{i}(\mathrm{nM})$} \\
\hline Muscimol & $7.1 \pm 0.5$ \\
GABA & $140 \pm 12$ \\
Bicuculline & $1400 \pm 90$ \\
I.-Baclofen & $>2 \times 10^{-4}$ \\
Nipecotic acid & $>1 \times 10^{-4}$
\end{tabular}

${ }^{3} \mathrm{H}$-muscimol binding to granule cell monolayers was performed as described in the Materials and Methods. The mean inhibitory concentration $\left(\mathrm{IC}_{50}\right)$ was obtained from a semilogarithmic plot of the dose-response curve derived from the ligand inhibition of ${ }^{3} \mathrm{H}$-muscimol binding. The inhibition constant $\left(K_{l}\right)$ was calculated by the equation: $K_{i}=\mathrm{IC}_{50} / 1+[\mathrm{L}] / K_{d}$, where [L] is the radioligand concentration ( $5 \mathrm{nM}$ for muscimol, $40 \mathrm{nM}$ for GABA and bicuculline inhibition) and $K_{d}$ is the dissociation constant of the ligand, obtained from the Scatchard plot (Fig. 1A). The values represent the means \pm SEM of 3 separate experiments.

buffer. After extensive washing, the immunoglobulins were eluted with 0.1 M citrate buffer, $\mathrm{pH} 3$.

\section{Immunohistochemistry}

After $8 \mathrm{~d}$ in culture, the dishes containing primary cultures of cerebellar interneurons were washed with $0.1 \mathrm{M}$ PBS $(\mathrm{pH} 7.4)$ and then fixed with $4 \%$ paraformaldehyde in PBS for $10 \mathrm{~min}$ at $25^{\circ} \mathrm{C}$. The cells were first incubated for $20 \mathrm{~min}$ with a 1:10 dilution of normal goat serum (NGS) and then incubated with the specific antisera in PBS containing $0.1 \%$ NGS at $4^{\circ} \mathrm{C}$ for $24 \mathrm{hr}$. In order to block axonal transport, some dishes were treated with colchicine $\left(10^{-6} \mathrm{M}\right)$ at $37^{\circ} \mathrm{C}$ for $12 \mathrm{hr}$ prior to the staining. The following antisera were used:

1. the polyclonal anti-GM antiserum;

2. the monoclonal antibody (mouse hybrid cells, clone G-A-5) to glial fibrillary acidic protein (GFAP; Boehringer Mannheim, Indianapolis, IN), which cross-reacts with $55 \mathrm{~K}$ intermediate filaments in astrocytes and Bergman glia but is not reactive with neurotilaments (Debus et al., 1983);

3. the monoclonal antibody (mouse hybrid cells, clone V-9) antivimentin (AV; Boehringer Mannheim), which cross-reacts with $57 \mathrm{~K}$ intermediate filaments in connective tissue, endothelial cells and astrocytes but is not reactive with nerve processes (Osborn et al., 1984);

4. the monoclonal mouse antibody against neurofilaments (NF) (Sternberger-Meyer, Jarretsville), which cross-reacts with 150 and 200 $\mathrm{K}$ neurofilaments in neurons but does not react with filaments in astrocytes (Debus et al., 1983); and

5. the polyclonal anti-glutamic acid decarboxylase (GAD, E.C 4.1.1.15), a generous gift from Dr. Kopin, National Institutes of Health, Bethesda, MD (Oertel et al., 1980).

For optimal staining, saponin $(0.1 \%)$ was present in the incubation medium in the case of GFAP, NF, and GAD antibodies; GM immunostaining was not modified by saponin treatment. The anti-GM antiserum was diluted 1:800, GFAP 1:200, AV 1:160, GAD 1:200, and NF $1: 1000$. For double immunofluorescence staining the cells were incubated with a mixture of anti-GM, plus GFAP or AV or GAD or NF antibodies. The incubation was terminated by several washings followed by incubation with the secondary antibodies $(1: 150)$ in PBS plus $0.1 \%$ NGS for $15 \mathrm{~min}$. Secondary antibodies were affinity-purified goat antimouse IgG conjugated with fluorescein isothiocyanate (FITC; Cappel) and goat anti-rabbit IgG conjugated with rhodamine isothiocyanate (RITC; Jackson Immunoresearch), or swine anti-rabbit IgG conjugated with rhodamine (Cappel) or swine anti-goat IgG conjugated with fluorescein (Boehringer Mannheim). After washing, the cells were coverslipped with buffered glycerol and viewed by fluorescence microscopy (Leizt, Ortholux II). The specimens were photographed on Tri-X or Ektachrome film (Kodak, 400 ASA).

Control dishes were incubated with preimmune serum $(1: 200)$ or with GM-antiserum preabsorbed with different amounts of GM or SMBP. Preabsorption was carried out by adding $5-20 \mu \mathrm{g} / \mathrm{ml}$ of the peptide to the GM-antiserum diluted $1: 800$ and incubated in PBS at $4^{\circ} \mathrm{C}$ overnight. Omission of either the link antiserum or the specific antiserum completely abolished the staining.

For immunohistochemistry of cerebellar slices, the rat brains were perfused with $4 \%$ paraformaldehyde solution for $20 \mathrm{~min}$ and further 

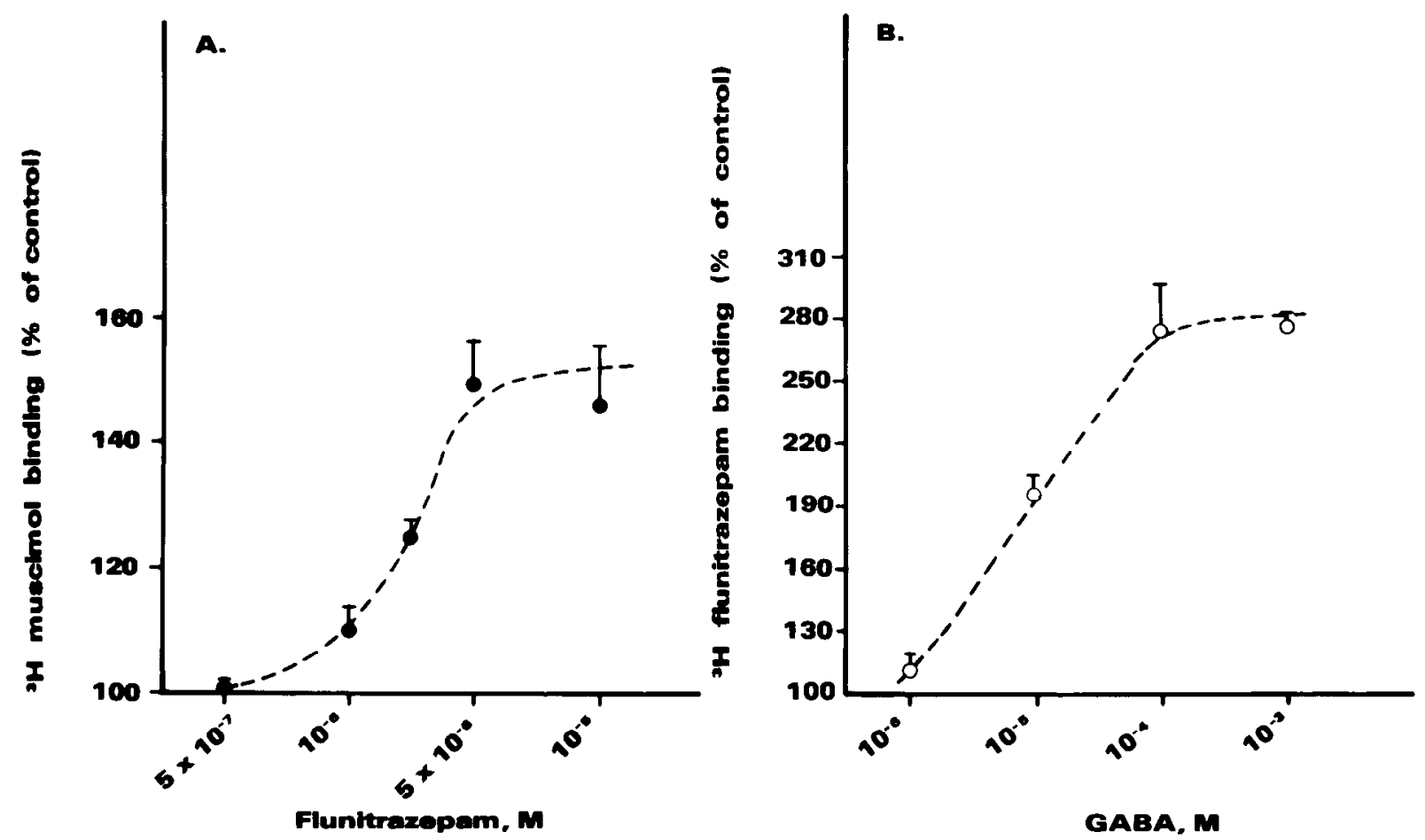

Figure 2. Reciprocal modulation of GABA $(A)$ and BZ $(B)$ binding sites in granule cell monolayers. ${ }^{3} \mathrm{H}$-muscimol $(A)$ and ${ }^{3} \mathrm{H}$-flunitrazepam $(B)$ specific binding was performed in intact cells as described, using $20 \mathrm{nM}{ }^{3} \mathrm{H}$-muscimol and $2.6 \mathrm{nM}{ }^{3} \mathrm{H}$-flunitrazepam, in the presence of different concentrations of unlabeled flunitrazepam and GABA, respectively. Control binding was $400 \pm 48 \mathrm{fmol} / \mathrm{mg}$ protein for ${ }^{3} \mathrm{H}$-muscimol and $94 \pm$ $5.0 \mathrm{fmol} / \mathrm{mg}$ protein for ${ }^{3} \mathrm{H}$-flunitrazepam.

processed for peroxidase-antiperoxidase immunostaining according to Sternberger (1979). The optimal dilution for GM antiserum was 1:1200, and the immunolabeling was visualized with 3,4-diaminobenzidine reaction (Sternberger, 1979)

\section{Purification of GM from cultured granule cells}

Primary granule cell cultures at $8 \mathrm{~d}$ of in vitro growth were extracted with $1 \mathrm{M}$ acetic acid, homogenized with Politron, boiled for $5 \mathrm{~min}$, and centrifuged. The crude extract was applied on a Sephadex G-75 column $(1 \times 80 \mathrm{~cm})$ eluted with $1 \mathrm{~m}$ acetic acid, the fractions containing the anti-GM immunoreactivity were pooled, lyophilized, and applied on a HPLC reverse-phase system. The HPLC conditions were as follows: $\mu$ Bondapak $\mathrm{C}_{18}$ preparative column $(7.8 \mathrm{~mm} \times 30 \mathrm{~cm}$; Waters Associates, Milford, MA) equilibrated with $0.1 \%$ TFA in water and eluted with a nonlinear gradient of acetonitrile containing $0.1 \%$ TFA (from 0 to $20 \%$ in $5 \mathrm{~min}$, then from 20 to $40 \%$ in $100 \mathrm{~min}$; flow rate, $2 \mathrm{ml} /$ min). GM purified from granule cells as well as from rat brain synaptosomes eluted with a retention time of $47 \mathrm{~min}$. In some cases, a partial purification of GM was achieved by absorption of the crude extract on a $\mathrm{C}_{18}$ Sep-Pak cartridge (Waters) eluted with $3 \mathrm{ml}$ of $60 \% 2$-propanol containing $0.1 \%$ TFA.

\section{Polyacrylamide gel electrophoresis}

One-dimensional SDS gels $(0.75 \mathrm{~mm}$ thick $)$ were prepared according to Laemli (1970); proteins were stained with silver nitrate according to Merril et al. (1981).

\section{Amino acid analysis}

Hydrolysis of proteins and amino acid analysis were carried out as previously described (Vaccarino et al., 1985) using a Hitachi 835 highspeed automatic amino acid analyzer equipped with a data processor unit (Hitachi, Tokyo).

\section{Results}

Characterization of the granule cell cultures

Immunocytochemical analysis revealed that $8 \mathrm{~d}$ in vitro primary cultures of dissociated cells prepared from newborn rat cere- bellum contain approximately $92 \%$ small neurons, as detected by anti-neurofilaments antibody (NF), morphologically identifiable as granule cells; $3 \%$ GFAP-positive or AV-positive astroglial or connective tissue cells (Fig. 4, B, D); 4-5\% GADpositive interneurons (Fig. 6). These results are in agreement with previous reports (Kingsbury et al., 1985; Nicoletti et al., 1986).

Granule cells-enriched cerebellar cultures contain 6-7 nmol $\mathrm{GABA} / \mathrm{mg}$ protein and release approximately $0.02 \mathrm{nmol}$ of GABA in $1 \mathrm{ml}$ of Locke's solution after $20 \mathrm{~min}$ incubation at $25^{\circ} \mathrm{C}$. The amount of GABA in the extracellular medium, although small, could interfere in the determination of the binding characteristics of ${ }^{3} \mathrm{H}$-muscimol and ${ }^{3} \mathrm{H}$-flunitrazepam. It has been reported (Aloisi et al., 1985) that a change of the culture medium at day 7 results in a selective degeneration of GABAergic cells. Therefore, for the binding experiments, the GABAergic interneurons were eliminated from the culture using the above procedure. We confirmed that after this change in the medium the immunohistochemical signs of GAD-positive interneurons virtually disappeared from the cultures (data not shown) and GABA was undetectable in the medium $(<0.01$ nmol).

\section{Location of GABA and $B Z$ recognition sites in granule cell cultures}

Using granule cell intact monolayers free of GABAergic neurons, the binding of ${ }^{3} \mathrm{H}$-muscimol or ${ }^{3} \mathrm{H}$-flunitrazepam was measured at $25^{\circ} \mathrm{C}$ in Locke's solution to keep osmolarity and ionic conditions in the physiological range (see Materials and Methods). ${ }^{3} \mathrm{H}$-flunitrazepam saturation data are consistent with a single binding component having a $K_{d}$ of $11 \mathrm{nM}$ and a $B_{\max }$ of $0.45 \mathrm{pmol} / \mathrm{mg}$ protein (Fig. $1 B$ ). ${ }^{3} \mathrm{H}$-muscimol saturation data 


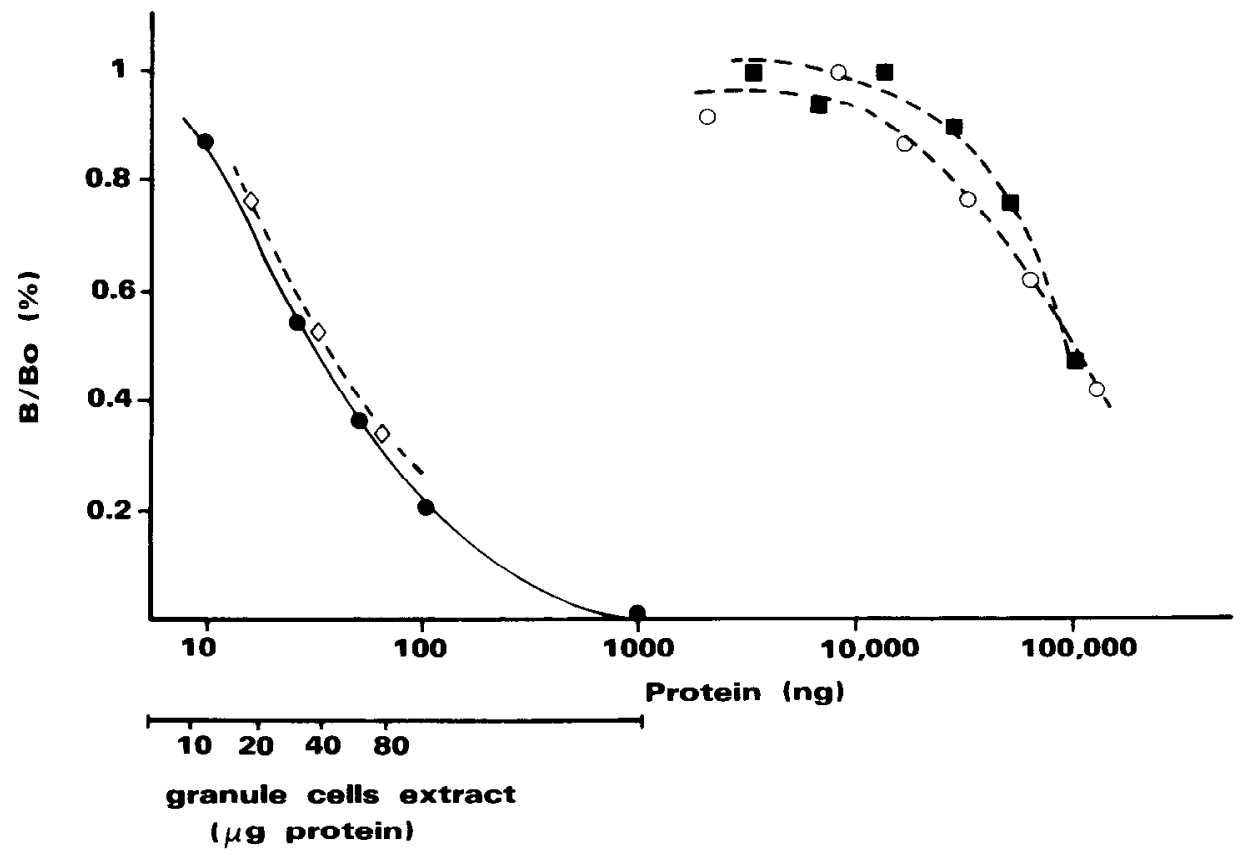

Figure 3. Immunoreactivity of the anti-GM antiserum against basic proteins and granule cell extract. The MBPs-preabsorbed antiserum raised against GM was assayed by RIA as described in Materials and Methods with standard GM purified from synaptosomes (O); SMBP (G) and LMBP (O) purified from rat brain myelin, and crude granule cell extract $(\diamond)$. indicate the presence of a single population of recognition sites having a $K_{d}$ of $12.5 \mathrm{~nm}$ and a $B_{\max }$ of $0.5 \mathrm{pmol} / \mathrm{mg}$ protein (Fig. $1 A$ ). Using membranes prepared from granule cells and suspended in Locke's solution, the Scatchard plots were linear for both ligands; the $K_{d}$ for ${ }^{3} \mathrm{H}$-flunitrazepam binding was $3.2 \mathrm{nM}$ and the $K_{d}$ for ${ }^{3} \mathrm{H}$-muscimol binding was 5 nM. The $B_{\max }$ was 1.2 and $0.9 \mathrm{pmol} / \mathrm{mg}$ protein for ${ }^{3} \mathrm{H}$-muscimol and ${ }^{3} \mathrm{H}$-flunitrazepam, respectively.

Table 1 shows the $K_{i}$ values of several $\mathrm{BZ}$ and beta-carboline derivatives for the displacement of ${ }^{3} \mathrm{H}$-flunitrazepam binding from intact granule cells; the order of potency of these ligands is comparable to that obtained in granule cell membranes. ${ }^{3} \mathrm{H}$ muscimol binding to intact monolayers was displaced by GABA agonists and antagonists with a rank order of potency similar to that reported for rat brain membranes: muscimol $>$ GABA > bicuculline (Table 2). Neither $10^{-4} \mathrm{M}$ nipecotic acid, an inhibitor of neuronal GABA uptake (Johnston et al., 1976), nor $2 \times 10^{-4}$ $\mathrm{M}$ baclofen, a $\mathrm{GABA}_{\mathrm{B}}$ receptor antagonist (Bowery et al., 1984), modified ${ }^{3} \mathrm{H}$-muscimol binding (Table 2 ).

In addition to high-affinity binding sites, intact cerebellar granule cells express low-affinity binding sites for GABA and $\mathrm{BZ}$, which reciprocally modulate each other. As shown in Figure 2, ${ }^{3} \mathrm{H}$-muscimol and ${ }^{3} \mathrm{H}$-flunitrazepam binding increased by the addition of micromolar concentrations of unlabeled flunitrazepam and GABA, respectively: $50 \%$ stimulation of ${ }^{3} \mathrm{H}$-muscimol binding was obtained with $2.5 \times 10^{-6} \mathrm{M}$ flunitrazepam, while $50 \%$ stimulation of ${ }^{3} \mathrm{H}$-flunitrazepam binding was achieved with $10^{-5} \mathrm{M}$ GABA. The effect of flunitrazepam on ${ }^{3} \mathrm{H}$-muscimol binding was blocked by the $\mathrm{BZ}$ antagonist RO15-1788 (control values: $280 \pm 20 \mathrm{fmol} / \mathrm{mg}$ protein; $5 \times 10^{-6} \mathrm{M}$ flunitrazepam: $380 \pm 9 \mathrm{fmol} / \mathrm{mg}$ protein; $5 \times 10^{-6} \mathrm{M}$ flunitrazepam plus $10^{-5}$ M RO15-1788: $290+27 \mathrm{fmol} / \mathrm{mg}$ protein; $n=3$ ).

\section{Location of GM in granule cells}

An antiserum was raised against GM purified from rat brain synaptosomes (Vaccarino et al., 1985) in order to establish whether granule cells contain GM in addition to GABA, BZ recognition sites and $\mathrm{Cl}^{-}$channels regulated by $\mathrm{GABA}$ (Guidotti et al., 1985). This antiserum originally showed a weak crossreactivity with MBPs, which was virtually eliminated by preabsorption of the antiserum with MBPs (see Materials and Methods). After preabsorption, the antiserum still retained a high affinity for GM ( $50 \%$ displacement of the radioactive tracer with 2 pmol of protein) but showed a 4000 -fold specificity for GM with respect to MBPs as assayed by RIA (Fig. 3). Thus, in all the subsequent experiments the anti-GM antiserum was routinely preabsorbed with MBPs.

\section{Expression of GM-like immunoreactivity in granule cells}

Immunohistochemically, the anti-GM antiserum brightly stained a uniform population of small neurons, morphologically iden-

Table 3. Immunofluorescent staining in primary cultures of cerebellar granule cells with anti-GM antiserum preabsorbed with different basic proteins

\begin{tabular}{cll}
$\begin{array}{c}\text { Antiserum } \\
\text { preabsorption }\end{array}$ & \multicolumn{2}{l}{ Immunofluorescent intensity } \\
\cline { 2 - 3 } GM $(\mu \mathrm{g} / \mathrm{ml})$ & Granule cells & Astrocytes \\
0 & +++ & 0 \\
5 & ++ & 0 \\
10 & + & 0 \\
20 & 0 & 0 \\
$\mathrm{SMBP}$ & & \\
0 & +++ & 0 \\
5 & +++ & 0 \\
10 & +++ & 0 \\
20 & ++ & 0 \\
\hline
\end{tabular}

At left is shown the amount of protein used in the preabsorption of the anti-GM antiserum. Immunohistochemical staining intensity was graded by comparison with dishes stained with preimmune serum: 0 , no reactivity (equal to preimmune) +++ , intense fluorescence; ++ , moderate fluorescence; + , weak scattered fluorescence.

Granule cells were identified by their reaction with NF antibody and morphology, and astrocytes by their reaction with GFAP antibody, both performed by doublestaining with anti-GM antiserum as described in the Materials and Methods. 

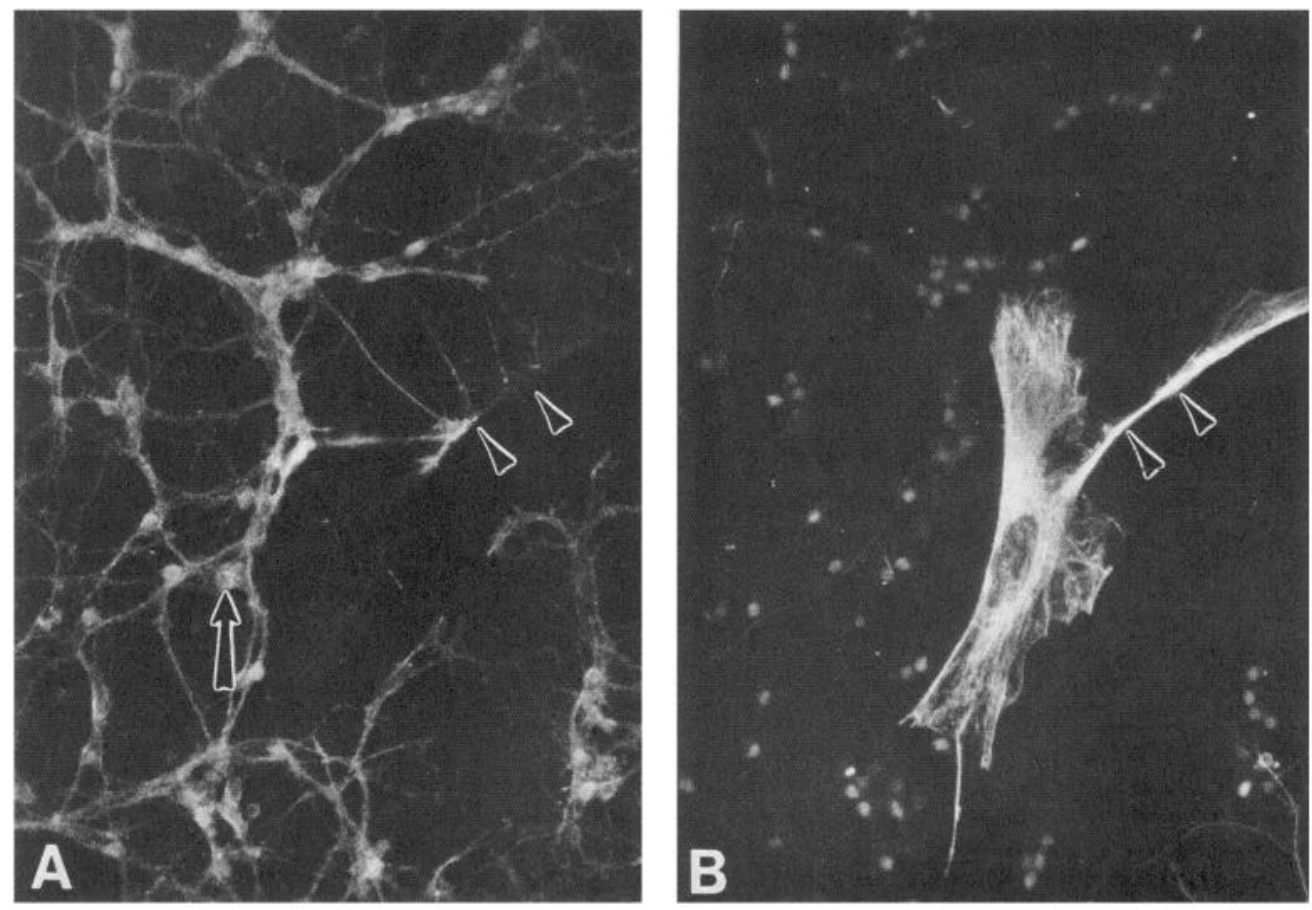

Figure 4. Fluorescence photomicrograph of cerebellar neuronal cultures enriched in granule cells, double-stained with anti-GM antiserum $(A, C)$ and either with anti-vimentin (VM) antiserum $(B)$ or with anti-glial fibrillary acidic protein (GFAP) antiserum $(D)$. In $A$, granule cells (arrow) and their fibers are stained with anti-GM antiserum; in $B$, the same field doublestained with VM antiserum shows a large epithelioid cell $(n)$ with a branch (arrowheads) that is not stained in $A$ with anti-GM ( $n$, arrowheads). In $C$ granular cells (arrow) are stained with anti-GM; in $D$, the same field doublestained with GFAP shows an astrocyte $(n)$ and branches (arrowheads) that are not stained in $C$ with anti-GM ( $n, a r$ rowheads). Bar, $30 \mu \mathrm{m}$ (all micrographs).
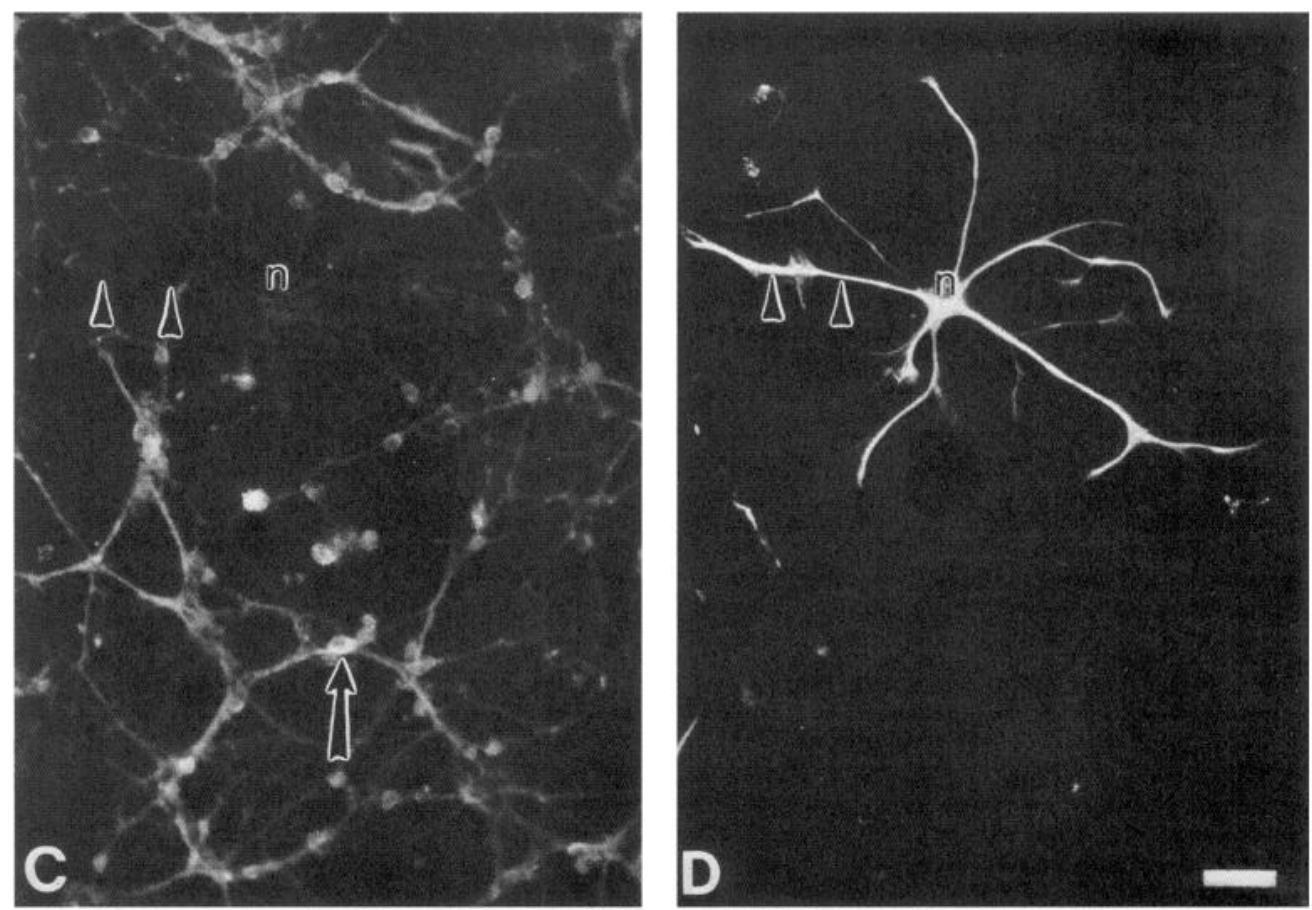

tifiable as the granule cells (Fig. 4, $A, C$ ), which were also immunoreactive for neurofilaments by double-immunostaining (data not shown). Astrocytes or other non-neuronal cells did not contain any GM-like immunoreactivity (Fig. $4, B, D$ ). When the cells in an identical incubation were treated with preimmune antiserum (1:200), only a faint fluorescence was observed (data not shown). Preabsorption of the anti-GM antiserum with $5 \mu \mathrm{g} /$ $\mathrm{ml}$ of GM diminished the stain, while $15 \mu \mathrm{g} / \mathrm{ml}$ of GM abolished it; however, $15 \mu \mathrm{g} / \mathrm{ml}$ of SMBP failed to diminish the staining (Table 3, Fig. 5). The immunoreactivity associated with the antiGM antiserum was absent in the nucleus and evident in the granule cell bodies, as well as along the cell processes (Fig. 5), and this pattern was unchanged with colchicine pretreatment (Fig. 6, $B, D$ ).

After incubation of the cultures with the anti-GAD antiserum, numerous GAD-positive fibers were detected (Fig. 6A). If the cultures were pretreated for $12 \mathrm{hr}$ with $10^{-6} \mathrm{M}$ colchicine, only GAD-positive neuronal cell bodies (3-4\% of the total neuronal population; Fig. $6, B, C$ ) were demonstrated; GAD-positive fibers and perikarya contained only traces of GM immunoreactivity, as demonstrated by double immunostaining (Fig. 6, $A-D)$. Routine histochemical studies were performed on cul- 

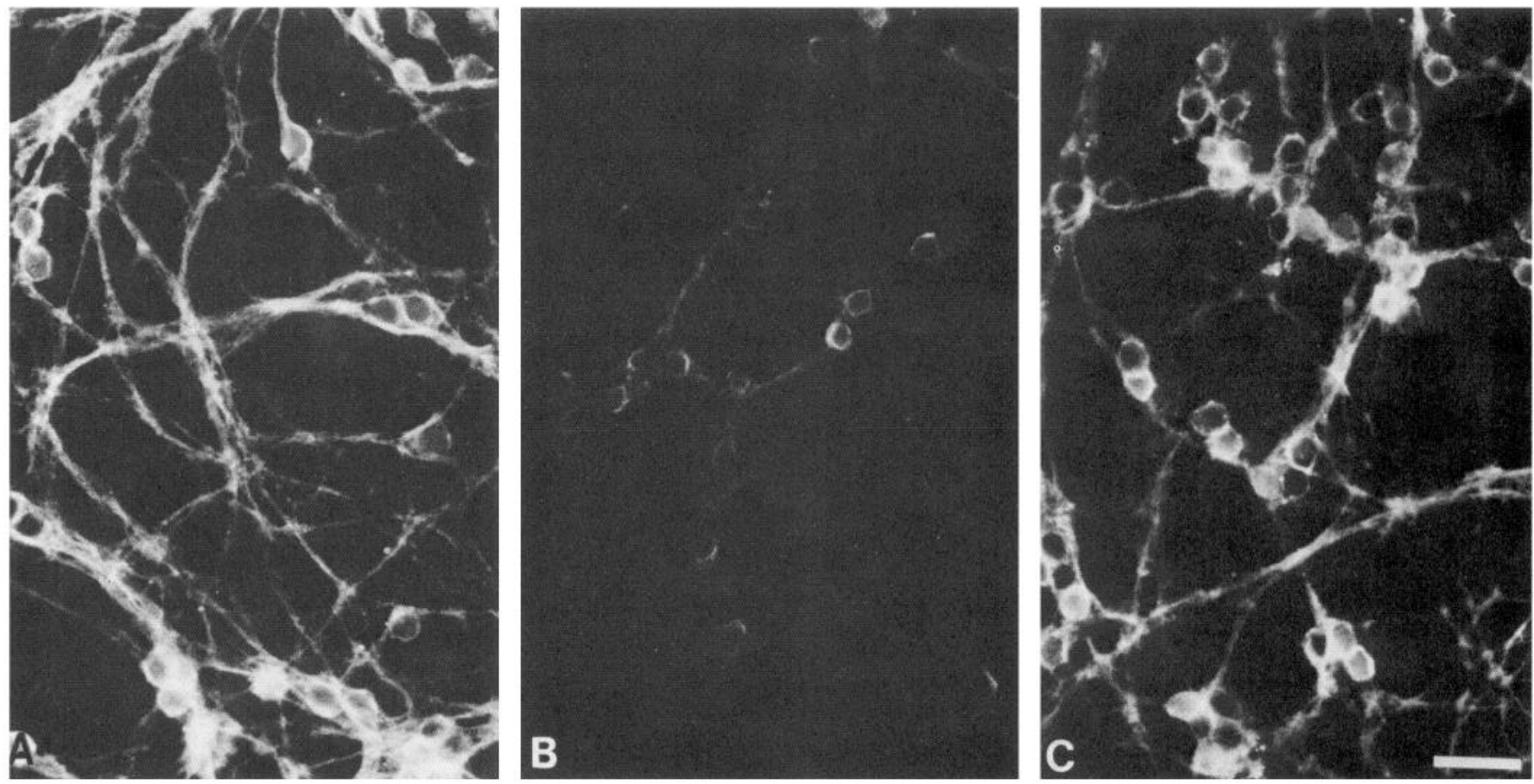

Figure 5. Fluorescence photomicrographs of cerebellar neuronal cultures enriched in granule cells. In $A$, cells stained with anti-GM antiserum; in $B$, corresponding field after preabsorption of the GM antiserum with $15 \mu \mathrm{g} \mathrm{GM}$, showing an almost complete abolition of staining. In $C$, the antiserum was preabsorbed with $15 \mu \mathrm{g} \mathrm{SMBP}$, showing that the staining was not considerably diminished. Bar $15 \mu \mathrm{m}$.

tures maintained in vitro without medium change for $8 \mathrm{~d}$; however, a medium change on day 7 (Aloisi et al., 1985), which results in the disappearance of the GAD staining, did not affect GM immunostaining in the granule cells (data not shown). Immunocytochemical studies were performed in rat cerebellar slices to address the issue of GM expression in neurons other than granule cells. As shown in Figure 7, a high density of GM immunoreactivity was present in the granule cell layer and a lower density in the molecular layer, where GM-like immunoreactivity was concentrated in the dendritic tree and cell body of the Purkinje cells (Fig. 7, $A, B$ ). The immunoreactivity was virtually abolished by preabsorption of the antiserum with $15 \mu \mathrm{g} / \mathrm{ml}$ of GM.

\section{Biochemical and immunological characteristics of $G M$ extracted from granule cells and from rat brain synaptosomes}

The amount of GM-like immunoreactive material present in the granule cells was determined by RIA using the MBPs-preabsorbed anti-GM antiserum, either on a crude granule cell extract or after partial purification through Sep-Pak cartridges (see Materials and Methods). In both cases, the concentration of GMlike immunoreactivity in granule cells was comparable. The concentration estimated after Sep-Pak purification was $1.2 \pm$ $0.09 \mu \mathrm{g} / \mathrm{mg}$ protein (average of 4 determinations). Identical aliquots of granule cell extract were assayed in parallel with an antibody raised against MBPs (a generous gift of Dr. G. Hashim, St. Luke's Hospital Center, New York, NY), which has a 10fold specificity for MBPs with respect to GM and does not stain granule cells by immunocytochemistry (data not shown). The anti-MBPs antibody gave values below the detection level.
Table 4. Amino acid composition of GABA-modulin (GM) purified from primary cultures of cerebellar granule cells or rat brain synaptosomes

\begin{tabular}{lcc}
$\begin{array}{l}\text { Amino acid } \\
\text { residue }\end{array}$ & $\begin{array}{l}\text { Granule cell GM } \\
(\text { mol \%) }\end{array}$ & $\begin{array}{l}\text { Synaptosomal } \\
\text { GM } \\
(\mathrm{mol} \%)\end{array}$ \\
\hline Asp & 7.5 & 7.8 \\
Thr & 4.4 & 5.5 \\
Ser & 8.6 & 8.6 \\
Glx & 11.2 & 10.7 \\
Pro & 7.0 & 8.2 \\
Gly & 13.2 & 11.6 \\
Ala & 9.0 & 8.1 \\
Cys & - & - \\
Val & 5.5 & 4.2 \\
Met & 1.4 & 1.5 \\
Ile & 3.3 & 3.0 \\
Leu & 5.8 & 5.4 \\
Tyr & 1.9 & 1.6 \\
Phe & 3.1 & 3.7 \\
Lys & 7.4 & 8.3 \\
His & 3.2 & 3.7 \\
Arg & 7.9 & 7.6 \\
Trp & - & - \\
Total & 100.4 & 99.5 \\
\hline
\end{tabular}

GM extracted from granule cells was purified as described in Materials and Methods; GM from rat brain synaptosomes was purified as described by Vaccarino et al. (1985). The values represent moles of amino acid per $100 \mathrm{~mol}$ of total amino acid recovered after $22 \mathrm{hr}$ of hydrolysis. Trp was destroyed during the analysis. Data for granule cell-derived GM represent the average analyses of 2 different preparations; data for GM are the average of 10 preparations. 

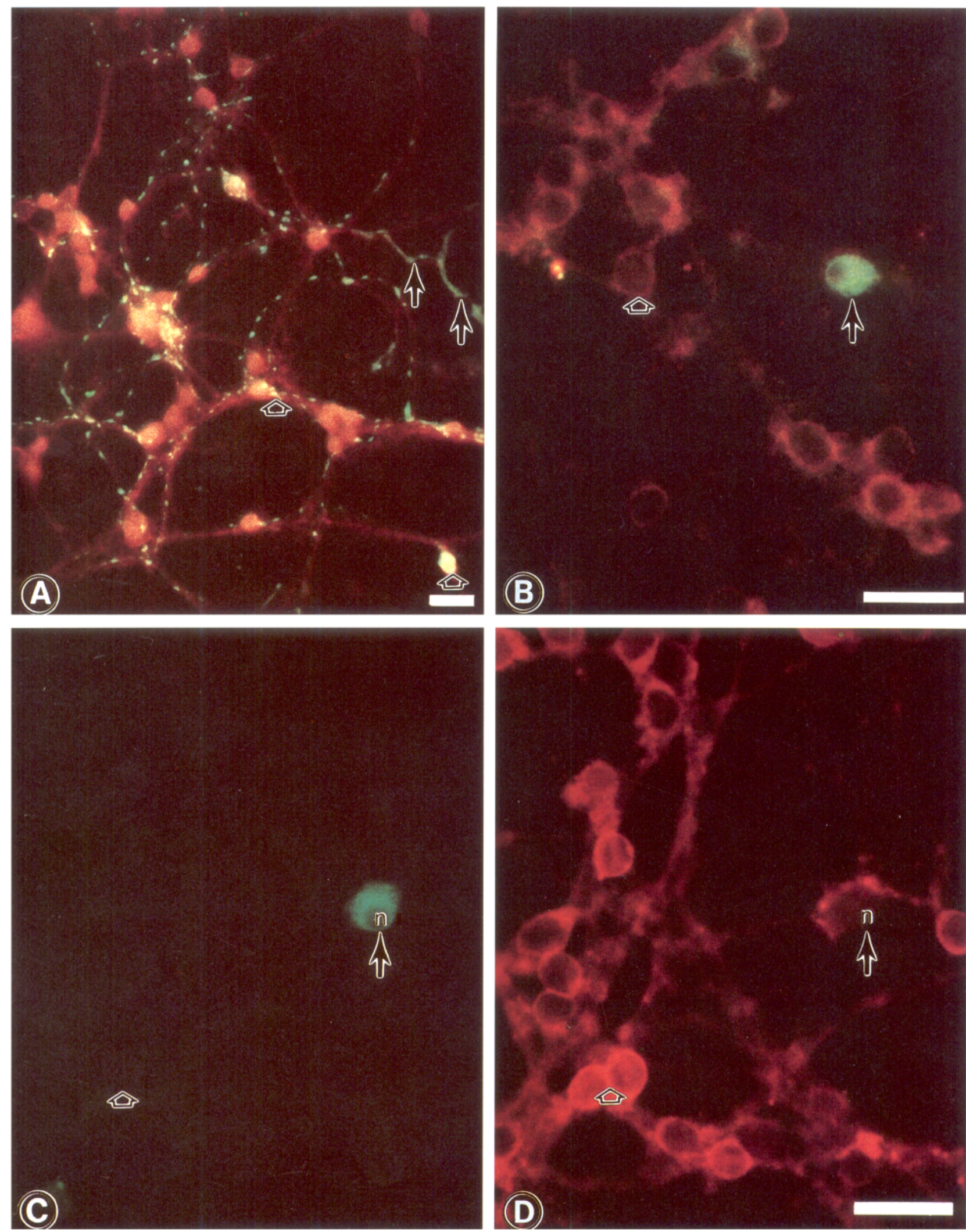

Figure 6. Fluorescence photomicrographs of cerebellar neuronal cultures enriched in granule cells, double-stained with GM (red) and with glutamic acid decarboxylase (GAD, green) antisera. In $A$, a double-stained/double-exposed field showing that the majority of the cells (granule cells) and fibers are stained red with the GM antiserum, while some fibers (arrows) are stained green with the GAD antiserum only. Note that when the structures containing the 2 antigens are superimposed, the color turns to yellow (short arrows). In $B$, a double-stained/double-exposed colchicinetreated culture showing several GM-positive cells (short arrow) and fibers, and 1 GAD-positive cell body (arrow) containing only a faint GMstaining. $C$ and $D$, Double staining with single exposure: $C$, GAD staining in colchicine-treated culture demonstrating 1 GAD-positive cell body 

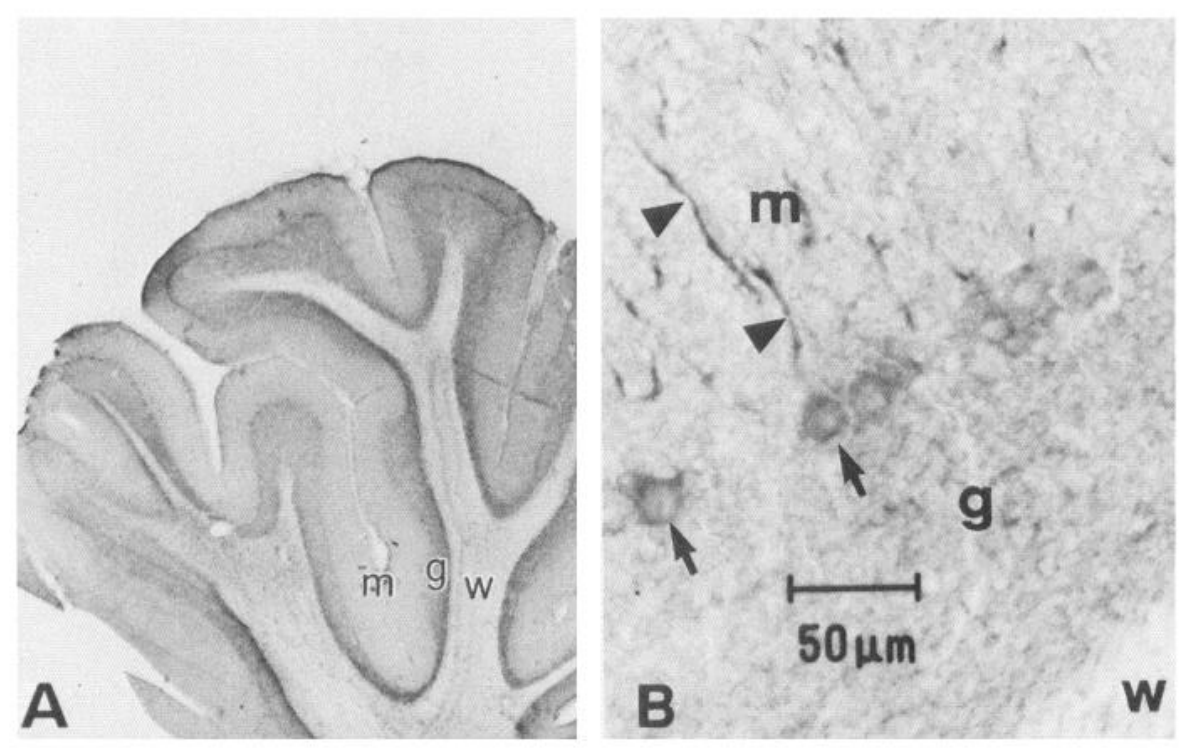

Figure 7. GM immunostaining in rat cerebellum. $A$, Low-magnification view demonstrating that the immunoreactivity is localized mainly in granular layer $(\times 15)$. $B$, High-magnification view showing that some Purkinje cells (arrow) and dendritic trees (arrowhead) are also stained $(\times 450)$.
The identity between the immunoreactive material extracted from granule cells and authentic GM purified from rat brain synaptosomes was established in 3 parallel ways.

1. Immunologically. A crude acetic acid extract from granule cells yielded a single immunoreactive peak on reverse-phase HPLC (Fig. 8), and this peak exactly coeluted with purified GM from rat brain synaptosomes. RIA of different dilutions of the extract with the anti-GM antiserum yielded a displacement curve with a slope identical to that given by increasing concentrations of a GM standard (Fig. 3).

2. Biochemically. After purification to homogeneity (see Materials and Methods), the GM-like immunoreactive material extracted from granule cell cultures had an identical retention time on reverse-phase HPLC and a similar amino acid composition to synaptosomal GM (Table 4). Moreover, SDS-PAGE produced a single protein band comigrating with synaptosomal GM and corresponding to an apparent molecular weight of about 17,000 (Fig. 9).
3. Functionally. GM extracted and purified from granule cells as described in (2) inhibited the binding of ${ }^{3} \mathrm{H}$-muscimol to Triton-X-100-treated rat brain membranes (Fig. 10) and to membranes prepared from granule cell cultures (data not shown) with a potency comparable to synaptosomal $\mathrm{GM}\left(\mathrm{IC}_{30}=0.5\right.$ $\mu \mathrm{M})$. Preincubation of GM with the anti-GM antibody purified with protein A-Sepharose did not abolish the inhibitory activity, suggesting that the functionally active site of GM is different from the immunoreactive epitope.

\section{Discussion}

The main finding emerging from this study is that intact cerebellar granule cells in primary culture, which express GABA and $B Z$ recognition sites on the cell surface, contain high amounts of GM, an endogenous basic polypeptide that modulates the number of GABA binding sites.

The pharmacological properties of ${ }^{3} \mathrm{H}$-muscimol and ${ }^{3} \mathrm{H}$-flunitrazepam binding sites measured on intact granule cell mono-

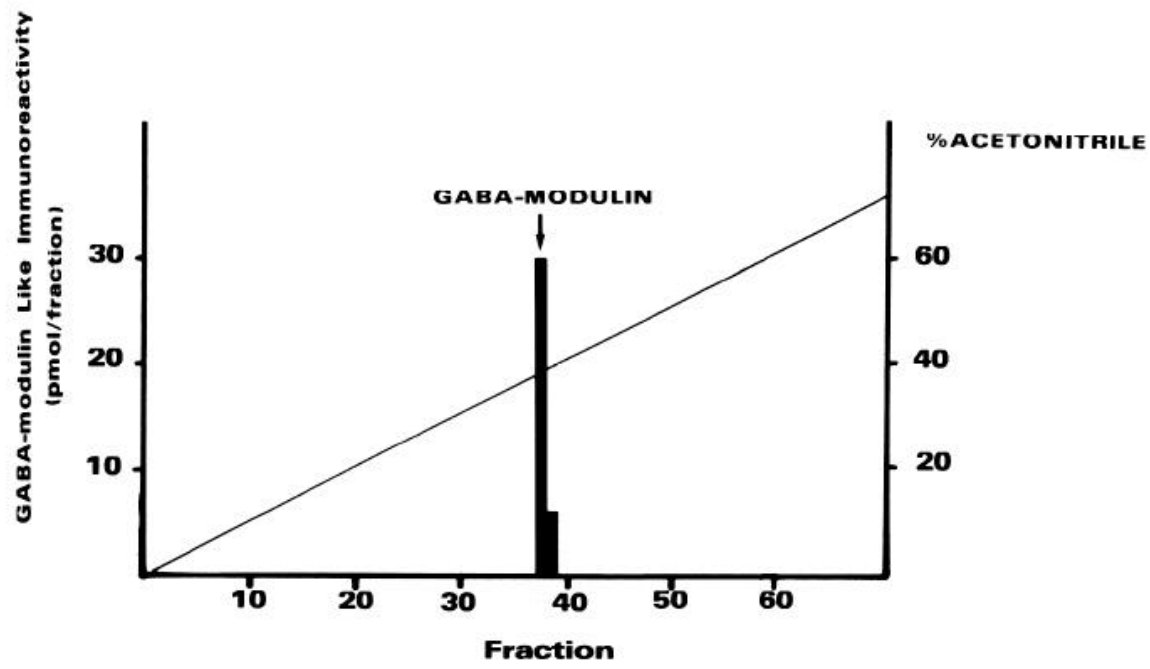

Figure 8. HPLC chromatography of crude granule cells extract. A crude acetic acid extract from granule cell cultures was directly applied on a HPLC system equipped with a $\mu$-Bondapak reverse-phase column (see Materials and Methods). Each fraction $(2 \mathrm{ml})$ was lyophilized and radioimmunoassayed. The retention time of authentic GM purified from rat brain synaptosomes is indicated by the arrow. 
Figure 9. SDS-PAGE of purified basic proteins. GM purified from rat brain synaptosomes ( $S y n-G M, 4 \mu \mathrm{g}$ ) and small myelin basic protein from myelin $(S M B P, 2 \mu \mathrm{g})$, were analyzed by SDS/ $15 \%$ polyacrylamide gel. The gel was stained with silver nitrate. The molecular-weight markers $(M r)$ used were BSA $(67,000)$, ovalbumin $(43,000)$ carbonic anhydrase $(30,000)$, soybean trypsin inhibitor $(20,100)$, and $\alpha$-lactalbumin $(14,400)$. Proteins migrated towards the anode.

\section{SDS-PAGE}

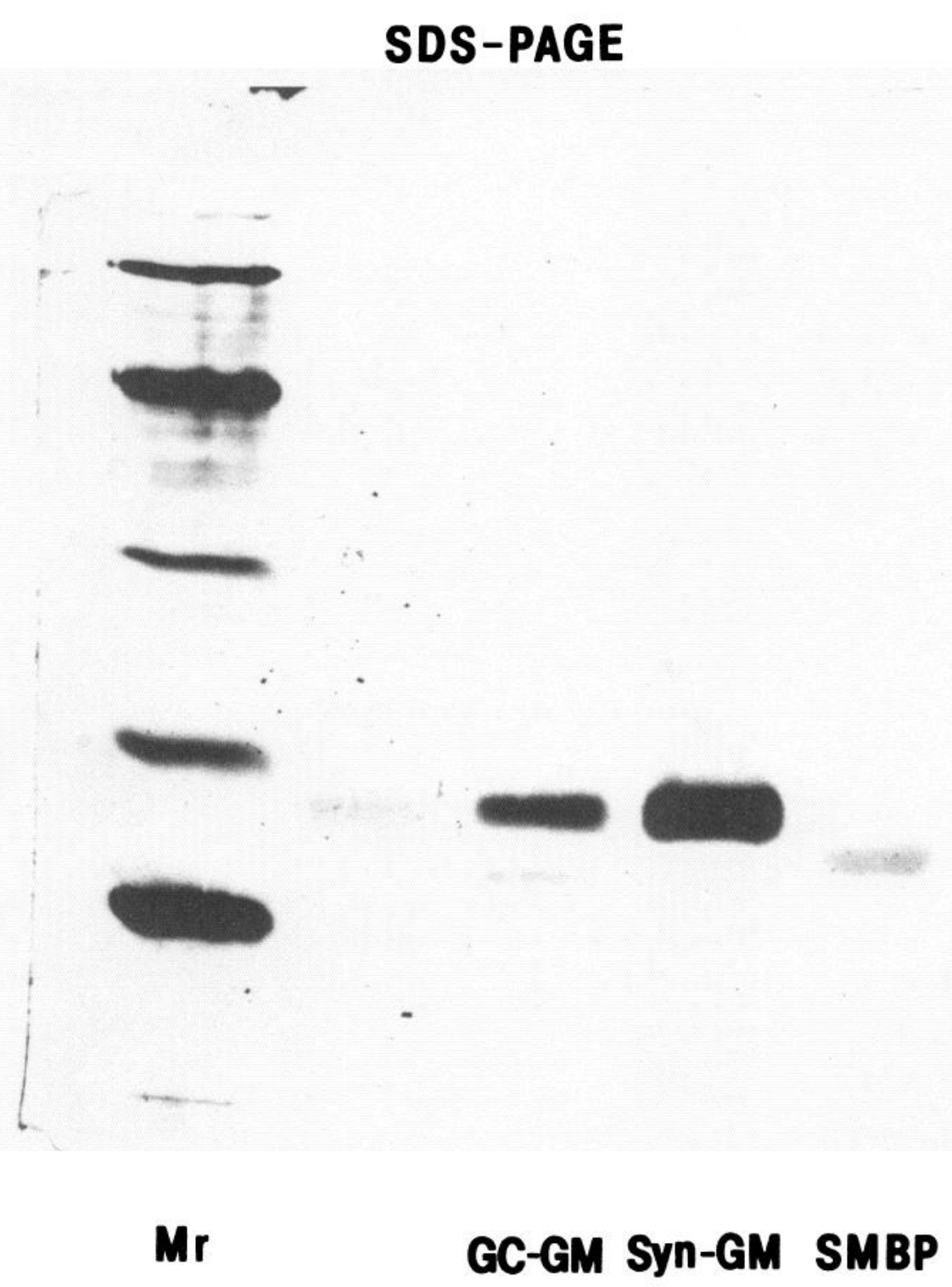

GC-GM Syn-GM SMBP

been measured in granule cell cultures under voltage-clamp conditions; moreover, $\mathrm{BZ}$ increase and beta-carbolines decrease GABA-evoked $\mathrm{Cl}^{-}$- conductance (Guidotti et al., 1985; Vicini et al., 1986).

Taken together, these data support the notion that, under assay conditions that preserve the integrity of the cell membrane and the microenvironment of the receptors, the components of the $\mathrm{GABA} / \mathrm{BZ} / \mathrm{Cl}^{-}$receptor-ionophore complex influence each other allosterically.

The allosteric regulation between the different recognition sites could involve additional modulators which are part of the supramolecular domain of the GABA receptor complex. Our data demonstrate that $\mathrm{GM}$, a polypeptide with regulatory properties on ${ }^{3} \mathrm{H}$-muscimol and ${ }^{35} \mathrm{~S}-\mathrm{TBPS}$ binding (Guidotti et al., 1982; Seifert and Casida, 1986) coexist with the $\mathrm{GABA} / \mathrm{BZ} / \mathrm{Cl}^{-}$receptor-ionophore complex in the granule cells. Moreover, we have demonstrated that the GM present in the granule cells is identical immunologically, biochemically, and functionally to GM purified from rat brain synaptosomes.

In cerebellar primary cultures, GM is selectively expressed 


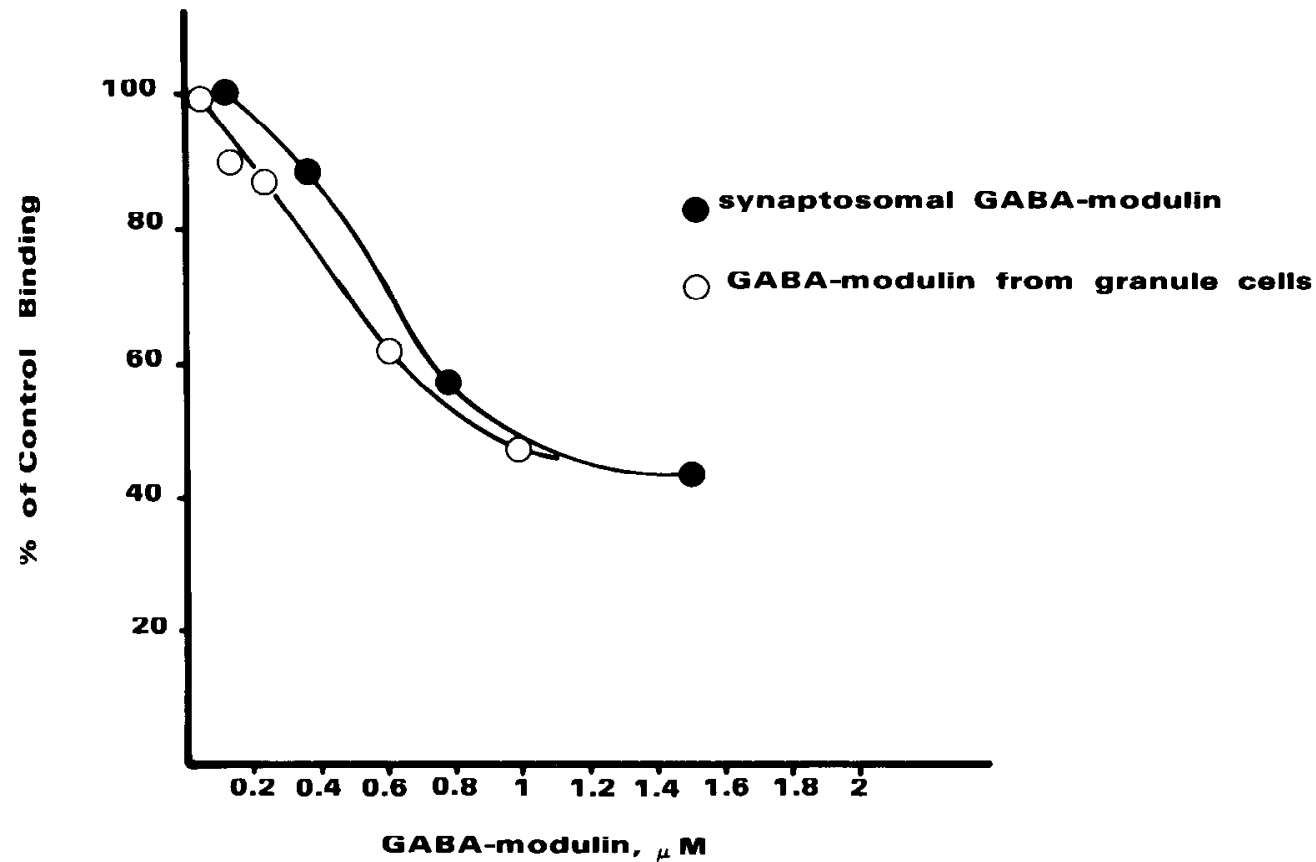

Figure 10. Inhibition of ${ }^{3} \mathrm{H}$-muscimol binding by GM extracted from synaptosomes or cerebellar granule cells. Crude rat brain membranes, prepared according to Enna and Snyder (1977), were treated with Triton X-100 $(0.05 \%)$ for $30 \mathrm{~min}$ at $37^{\circ} \mathrm{C}$, washed 3 times in Tris buffer, and incubated with ${ }^{3} \mathrm{H}-$ muscimol for $5 \mathrm{~min}$ at $0-4^{\circ} \mathrm{C}$ in the presence of different concentrations of GM. The concentration of membranes was $150-200 \mu \mathrm{g}$ per assay, and the concentration of ${ }^{3} \mathrm{H}$-muscimol was $10 \mathrm{nM}$. by granule cells; in fact, GM is not detectable in glial or other contaminating cells (Fig. 4, $A-D$ ), and only a trace amount is visualized in the cell bodies or fibers of GAD-positive interneurons-presumably Golgi, basket, or stellate cells (Fig. 6, A$D$ ). Interestingly, the pattern of immunostaining of the cultures by the GM antiserum was unchanged by colchicine pretreatment (Fig. 6, $B, D$ ). These data provide the first evidence that GM is selectively located in a population of neurons that functionally receive a strong $\mathrm{GABA}$ input and contain $\mathrm{GABA}$ receptors.

To address the question of whether the coexistence of GM with the GABA/BZ/C1- ionophore-receptor complex observed in granule cells can be extended to other GABA-receptor-containing neurons, we performed immunocytochemical studies in rat cerebellar sections. This tissue was selected in order to visualize histochemically the density of GM-like immunoreactivity in granular, molecular, and Purkinje cell layers, in which the expression of GABA receptors has been extensively studied using monoclonal antibodies (Schoch et al., 1985) and autoradiography (Hosli et al., 1980; Schoch et al., 1985). The distribution of GM-like immunoreactivity in cerebellar sections is similar to the reported immunocytochemical localization of GABA receptors; interestingly, Purkinje cell bodies, which are known to be rich in GABA/BZ binding sites (Hosli et al., 1980), contain a high density of GM-like immunoreactivity.

The relatively high concentration of GM in granule cells (1.2 $\mu \mathrm{g} / \mathrm{mg}$ protein) should not be surprising in view of its proposed modulatory role on GABA receptors (Guidotti et al., 1982); in fact, $G_{1}$ and $G_{0}, 2$ other regulatory proteins that bind GTP, account for more than $1.5 \%$ of the total membrane protein (Sternweis and Robishaw, 1984).

Given the known similarity in amino acid composition and peptide mapping between GM and SMBP (Vaccarino et al., 1985), we determined whether GM is the only basic protein present in granule cells, using antibodies specific for GM and/ or MBPs. With RIA and immunocytochemistry, we detected GM, but not MBPs, in granule cells in primary culture. Thus, it seems that basic proteins in the brain comprise a family of proteins localized in different cell types and with cell-specific functions. The ability to detect GM in neurons with a specific antiserum permits us to investigate the mechanism of its GABA binding inhibitory activity in detail. It is known that GM can be phosphorylated in vitro (Wise et al., 1983), and this phosphorylation abolishes its capacity to inhibit GABA binding. Studies utilizing granule cell cultures could investigate the physiological stimuli that trigger the phosphorylation of GM in the cells. A theoretical framework could be provided to explain the regulation of GABA receptor by GM and phenomena such as super- or desensitization of GABA receptors.

\section{References}

Allen A. J., and G. R. Dutton (1984) ${ }^{3} \mathrm{H}$ Flunitrazepam binding to neuron-enriched cerebellar cultures. Pharmacologist 26: 180 .

Aloisi F., M. T. Ciotti, and G. Levi (1985) Characterization of GABAergic neurons in cerebellar primary cultures and selective neurotoxic effects of a serum fraction. J. Neurosci. 5: 2001-2008.

Balazs R., C. M. Regan, R. D. Gordon, P. Annunziata, A. E. Kingsbury, and E. Meier (1982) Certain surface properties of isolated and cultured cerebellar cells. In Neurotransmitter Interaction and Compartmentalization, $\mathrm{H}$. Bradford, ed., pp. 515-534, Plenum, New York.

Bowery, N. A., G. W. Price, A. L. Hudson, G. P. Hill, P. G. Wilkin, and M. J. Turnbull (1984) Visualization of different receptor types in the mammalian CNS. Neuropharmacology 23: 219-231.

Calabrese, V. P. (1984) A micromethod for absorption of specific antibody using an enzyme-linked immunosorbent assay (ELISA). J. Neurosci. Methods 11: 137-141.

Cockcroft S., and B. D. Gomperts (1985) Role of guanine nucleotide binding protein in the activation of polyphosphoinositide phosphodiesterase. Nature 314: 534-536.

Costa E., and A. Guidotti (1979) Molecular mechanisms in the receptor action of benzodiazepines. Annu. Rev. Pharmacol. Toxicol. 19: 531-545.

Debus E., K. Weiber, and M. Osborn (1983) Monoclonal antibodies specific for glial fibrillary acidic (GFA) protein and each of the neurofilament triplet polypeptides. Differentiation 25: 193-203.

Dunkley P. R., and P. R. Carnegie (1974) Amino acid sequence of the smaller basic protein from rat brain myelin. Biochem. J. 14I: 243-255.

Enna S. J., and S. H. Snyder (1977) Influences of ions, enzymes, and 
detergents on $\gamma$-aminobutyric acid receptor binding in synaptic membranes of rat brain. Mol. Pharmacol. 13: 442-453.

Gallo, V., M. T. Ciotti, A. Coletti, F. Aloisi, and G. Levi (1982) Selective release of glutamate from cerebellar granule cells differentiating in culture. Proc. Natl. Acad. Sci. USA 79: 7919-7923.

Gallo V., B. C. Wise, F. Vaccarino, and A. Guidotti (1985) $\gamma$-Aminobutyric acid- and benzodiazepine-induced modulation of $\left[{ }^{35} \mathrm{~S}\right]-\mathrm{t}-$ butylbicyclophosphorothionate binding to cerebellar granule cells. J. Neurosci. 5: 2432-2438.

Guidotti A., D. R. Konkel, B. Ebstein, M. G. Corda, B. C. Wise, H. Krutzsch, J. L. Meek, and E. Costa (1982) Isolation, characterization, and purification to homogeneity of a rat brain protein (GABAmodulin). Proc. Natl. Acad. Sci. USA 79: 6084-6088.

Guidotti, A., P. Ferrero, R. Santi, H. Alho, S. Vicini, and E. Costa (1985) Gamma-aminobutyric acid and chloride channels: Regulation by neuropeptides. Regulatory Peptides Suppl. 4: 172-181.

Hosli E., H. Mohler, J. G. Richards, and L. Hosli (1980) Autoradiographic location of binding sites for $\left[{ }^{3} \mathrm{H}\right] \gamma$-aminobutyrate, $\left[{ }^{3} \mathrm{H}\right]$ muscimol, $(+)\left[{ }^{3} \mathrm{H}\right]$ bicuculline methiodide and $\left[{ }^{3} \mathrm{H}\right]$ flunitrazepam in cultures of rat cerebellum and spinal cord. Neuroscience 5: 16571665.

Johnston G. A. R., P. Krogsgaard-Larsen, A. L. Stephanson, and B. Twitchin (1976) Inhibition of the uptake of GABA and related amino acids in rat brain slices by the optical isomers of nipecotic acid. J. Neurochem. 26: 1029-1032.

Kingsbury A. E., V. Gallo, P. L. Woodhams, and R. Balazs (1985) Survival, morphology and adhesion properties of cerebellar interneurones cultured in chemically defined and serum-supplemented medium. Dev. Brain Res. 17: 17-25.

Laemli U. K. (1970) Cleavage of structural proteins during the assembly of the head of bacteriophage T4. Nature 227: 680-685.

Lefkowitz R. J., M. G. Caron, T. Michel, and J. "M. Stadel (1982) Mechanisms of hormone receptor-effector coupling: The $\beta$-adrenergic receptor and adenylate cyclase. Fed. Proc. 41: 2664-2670.

I evi G., F. Aloisi, M. T. Ciotti, and V. Gallo (1984) Autoradiographic localization and depolarization-induced release of acidic amino acids in differentiating cerebellar granule cell cultures. Brain Res. 290: 7786.

Lindmark R., K. Thoren-Tolling, and J. Sjoquist (1983) Binding of immunoglobulins to Protein $\mathrm{A}$ and immunoglobulin levels in mammalian sera. J. Immunol. Methods 62: 1-13.

Lowry O. H., N. J. Rosebrough, A. L. Farr, and R. J. Randall (1951) Protein measurement with the Folin phenol reagent. J. Biol. Chem. 193: $256-275$.

Massotti M., S. Mazzari, R. Schmid, A. Guidotti, and E. Costa (1981) Endogenous inhibitors of $\mathrm{Na}^{+}$-independent $\left[{ }^{3} \mathrm{H}\right]$-GABA binding to crude synaptic membranes. Neurochem. Res. 6: $551+565$.
Merril C. R., D. Goldman, S. A. Sedman, and M. H. Ebert (1981) Ultrasensitive stain for proteins in polyacrylamide gels shows regional variation in cerebrospinal fluid proteins. Science 211: 1437-1438.

Nicoletti F., J. T. Wroblewski, A. Novelli, H. Alho, A. Guidotti, and E. Costa (1986) The activation of inositol phospholipid metabolism as a signal-transducing system for excitatory amino acids in primary cultures of cerebellar granule cells. J. Neurosci. 6: 1905-1911.

Oertel, W. H., M. L. Tappaz, I. J. Kopin, D. H. Ransom, and D. E. Schmechel (1980) Production of an antiserum to rat brain glutamate (GAD)/cysteine sulfinate (CSD) decarboxylase. Brain Res. Bull. 5: 713-719.

Osborn M., E. Debus, and K. Weber (1984) Monoclonal antibodies specific for vimentin. Eur. J. Cell. Biol. 34: 137-143.

Rodbell M. (1980) The role of hormone receptors and GTP-regulatory proteins in membrane transduction. Nature 284: 17-22.

Schmid R., J. S. Hong, J. Meek, and E. Costa (1980) The effect of kainic acid on the hippocampal content of putative transmitter amino acids. Brain Res. 200: 355-362.

Schoch P., J. G. Richards, P. Haring, B. Takacs, C. Stahli, T. Staehelin, W. Haefely, and H. Mohler (1985) Co-localization of GABA receptors and benzodiazepine receptors in the brain shown by monoclonal antibodies. Nature 314: 168-171.

Seifert J., and J. E. Casida (1986) Basic neuroproteins modulate TBPS recognition site. Eur. J. Pharmacol. 122: 157-158.

Sternberger, L. A. (1979) Immunocytochemistry, 2nd ed., pp. 104169, Wiley, New York.

Sternweis P. C., and J. D. Robishaw (1984) Isolation of two proteins with high affinity for guanine nucleotides from membranes of bovine brain. J. Biol. Chem. 259: 13806-13813.

Tallman J. F., J. W. Thomas, and D. W. Gallager (1978) GABAergic modulation of benzodiazepine binding sites sensitivity. Nature 274: 383-385.

Vaccarino F., B. M. Conti-Tronconi, P. Panula, A. Guidotti, and E. Costa (1985) GABA-modulin: A synaptosomal basic protein that differs from small myelin basic protein of rat brain. J. Neurochem. 44: 278-290.

Vicini, S., J. T. Wroblewski, and E. Costa (1986) Pharmacological modulation of GABAergic transmission in cultured cerebellar neurons. Neuropharmacol. 25: 207-212.

Wilkin G. P., R. Balazs, J. E. Wilson, J. Cohen, and G. R. Dutton (1976) Preparation of cell bodies from the developing cerebellum: Structural and metabolic integrity of the isolated cells. Brain Res. 115: 181-199.

Wise B. C., A. Guidotti, and E. Costa (1983) Phosphorylation induces a decrease in the biological activity of the protein inhibitor (GABAmodulin) of $\gamma$-aminobutyric acid binding sites. Proc. Natl. Acad. Sci. USA 80 : $886-890$ 